\title{
Automotive Disc Brake and Its Numerical Analysis: A Literature Review
}

\author{
Nilesh G.Jawarkar ${ }^{1}$, Dr.G.K.Awari ${ }^{2}$, Dr. S. P. Trikal ${ }^{3}$ \\ ${ }^{1}$ Ph.D Scholar, ${ }^{3}$ Professor and Head, Department of Mechanical Engineering, Shri Sant Gajanan Maharaj College of \\ Engineering, Shegaon, SGBAU Amravati, Maharashtra, India. \\ ${ }^{2}$ Head, Department of Automobile Engineering, Government Polytechnic, Nagpur, Maharashtra,
}

Received on: 28 November, 2020, Revised on: 15 December, 2020, Published on: 25 December 2020

\begin{abstract}
The most significant feature of the car that ensures security and comfort is the brake. Over time, disc brakes have grown to be compatible to decelerate and stop the car. This is the most important aspect of the vehicle that is often showing the nonlinear thermo elastic transient conditions. For numerous uses, there are various prototypes of disc brake systems. A comprehensive overview of the different geometries of the components and numerical analysis of solid disc is given in this study. So many disc brakes related operating problems need to be understood by considering all the changes. Substantial studies on these challenges have been carried out and are continuing, and various approaches are being suggested to remove or minimize them at the same time. This research would be useful in explaining brake system changes and efficiency, in increased fuel consumption, and in reducing the weight of vehicles. And the products used in previous experiments and the use of various synthetic materials are also discussed. The analysis shows that, by actually emulating all the applicable realistic scenarios, there is ample space for extended research to realize optimum disc brake system architecture.
\end{abstract}

\section{I- INTRODUCTION}

$\mathbf{F}$ or stopping or changing speed under an evolving highway and traffic situation, a vehicle requires a braking system. Converting the kinetic energy into some useful energy is the fundamental concept used in braking systems. For starters, it is transformed into heating by friction braking, and conversion into electrical power in regenerative braking, etc. Only a few amounts of kinetic energy is transformed into the desired form during a braking process, e.g. some energy in the form of vibrations might be dissipated in friction braking[1]. The braking system unit [2] is one of the most important components of a car. Designing a braking device for achieving an optimal efficiency along with decreased packing requirement and weight is a task. The 3-D nonlinear transient thermo elastic state is revealed to a disc brake device [3]. A frictional torque must be resisted by the disc brake unit and thermal energy produced through braking must be dissipated [4]. The efficiency of the vehicle braking system is primarily influenced by an increase in the temperature during the braking of a pad interface and disc. Thermal distortion, premature wear, instability due to thermo elastic, thermal cracking, brake fading, vaporization of brake fluid, brake judder and squeal, bearing collapse, are caused by the increase in temperature. Many of these considerations have a significant effect on the life and working of the braking on the safety of vehicles and passengers [5-9].

The simple disc braking system is as shown in Figure 1. Two types of friction brakes are commonly used, such as drum brakes and disc brakes. Because of the wider swept area and comparatively higher sensitivity to airflow, disc brakes cool faster compared to drum brakes and exhibit self-cleaning capability due to centrifugal forces [10]. 


\section{International Journal of Innovations in Engineering and Science, www.ijies.net}

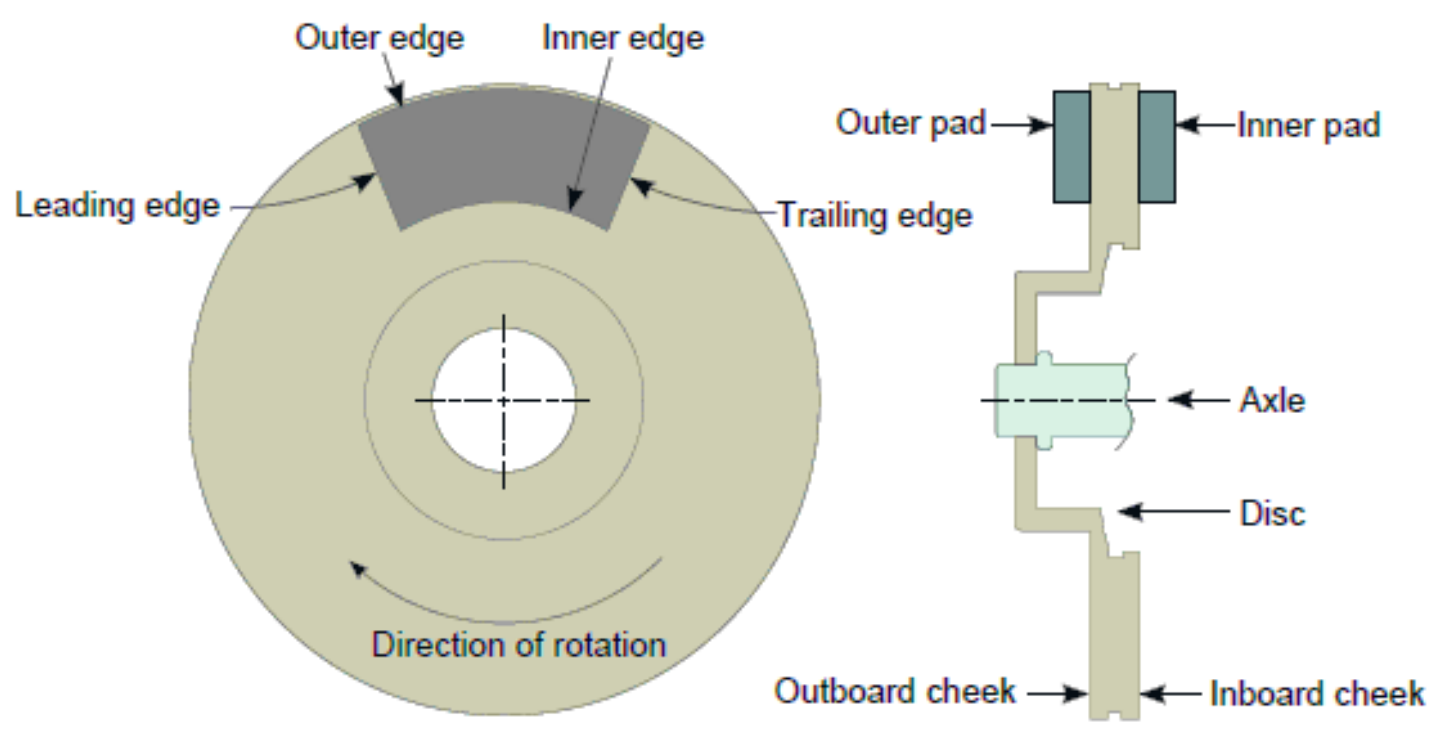

Fig 1- The simplistic disc braking system along widely used terminology

In disc brakes, a broad variety of phenomena occur, defined by terms such as thermal instability, normal strain, contact strain, thermal tension and distortion, thermal and structural deformation, thermo elastic transformation, thermal cracks, thermo elastic behavior, thermo-mechanical behavior, wear, coefficient of friction, hot spots, contact change, brake, and thermal judder, etc. [11-13]. Besides, if the slipping speed is greatly higher, the interaction between the disc and the pad becomes fragile [14-17]. If the thermal deformation formed near interface contact is not standardized, then the concentration contact is found on the nearest point of maximal deformation. As a result, in the region with the greatest frictional heating, strain, and highest rise in temperatures of the surface, resulting in the maximum thermal expansion [18].

The form of pressure distribution at the interface [19-20] is determined by these variables. The device pressure is assumed constant most of the time (assuming constant pressure) and is known to vary inversely with the radius in some cases. Though, the interface pressure is inconsistent and varies over time during dynamic braking applications, which induces a mixture of thermal/ mechanical distortions and interface wear [21$23]$.
This study paper consists of large introductory part sections, disc brake terms, solid rotor numerical analysis accompanied by conclusions. Different aspects of a disc brake mechanism are presented in the 'Disc brakes' section. The section on numerical analysis reviews the numerous published works on simple solid disc numerical analysis. Finally, some concluding remarks are offered in the 'Conclusion' portion.

\section{II- DISC BRAKES}

The collection of pads is pressed against a spinning rotor in a disc brake device and the temperature is produced on the interface of the disc-pad due to friction. Eventually, this heat is passed to the car and the atmosphere, and the disc cools off. In figure 1, a simpler disc brake is seen. The pad that is closest to the vehicle's middle is called the inboard pad, and the outboard pad is one that is removed. Likewise, the disc friction surface of facing the car is referred to as the inboard cheek and the outboard cheek is called the one facing forward. First, the side of the pad that contacted a point upon the surface of the disc is known as the leading side, and the trailing edge is called the edge that reaches the last point. The portion of the pad having a small radius is named the inner one, and the outer edge is named the one with a greater radius. 


\section{International Journal of Innovations in Engineering and Science, www.ijies.net}

As seen in figure 2, a disc brake assembly has the following main parts,

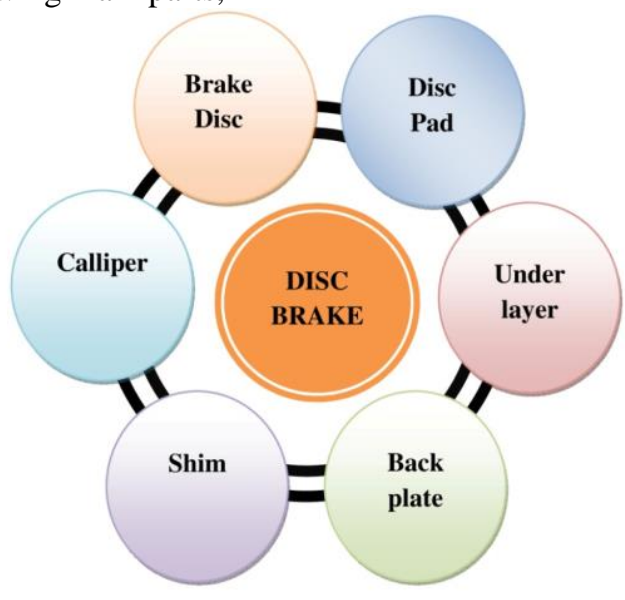

Fig 2- Major components of a disc brake assembly

\subsection{Brake disc}

The brake disc is attached to the axle, sometimes called the brake rotor, so that it rotates at an equal speed as a tyre. It is also vital that heat is dissipated as rapidly as possible for a successful brake design, or else the temperature of the disc may increase and influence the efficiency of the disc brake. Ventilation is applied into brake discs to achieve maximum efficiency in challenging conditions, which improves the cooling rate. It is possible to classify brake discs into two categories: 1. Strong discs for braking 2. Ventilated discs with pedals. The schematic representation of the various brake discs is shown in Figure 3, where (a) Ventilated disc without bell, (b) Ventilated disc with a bell, (c) Solid disc without bell, (d) Solid disc with a bell.

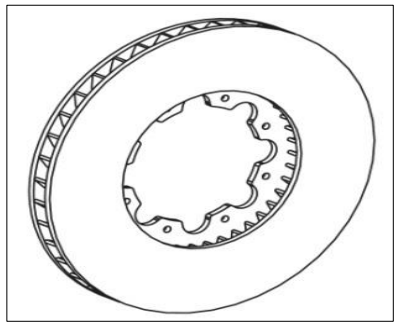

(a)

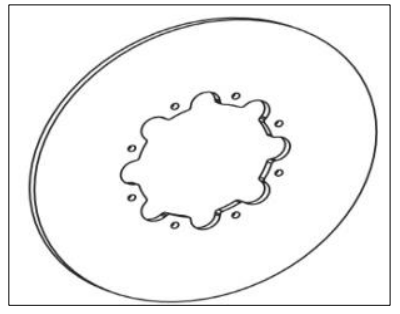

(c)

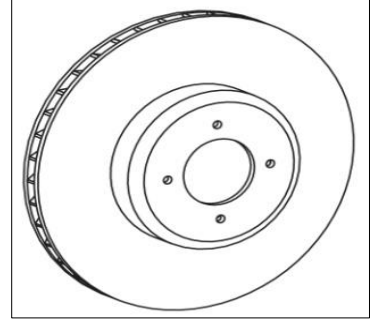

(b)

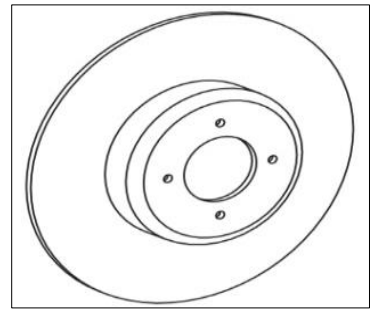

(d)

\subsection{Brake pad}

A friction substance and the back plate jointly are often known as a brake pad. It is attached to a back plate that appears into figure 4 . Slots on the profile and chamfers at the ends are usually built into a brake pad. The elimination of squeal noise [24, 25] is one reason for integrating chamfers and slots. Convex bending of the $\operatorname{pad}[26,27]$ results in a comparatively higher temperature on the outside of the pad than on the inside. A slot can encourage bending of the material and help prevent cracks. It also encourages the washing of the dust gathered by providing an exit between the disc and pad surfaces.

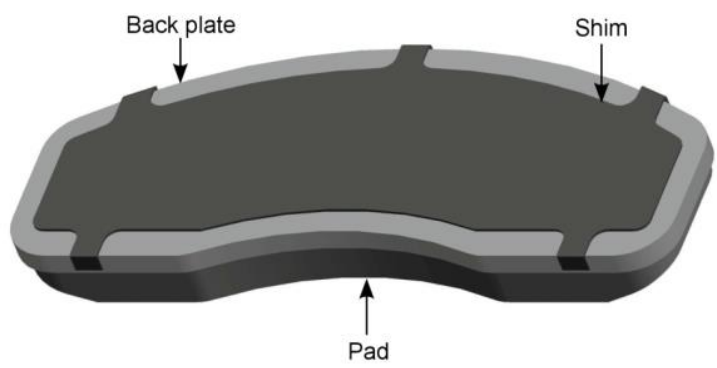

Fig 4- An assembly of backplate, shim, and pad

\section{a. Under layer}

The extra material layer is often placed between a back plate and friction material, called the under layer or base. Its primary objective is to dampen vibrations coming from the interface of the disc-pad[28].

\subsection{Back plate}

To sustain the friction material and transfer the actuation force, a back plate has been utilized. Friction content, adhesive bonding, and mechanical retention are often added to a back plate by a couple of methods. It's possible to accomplish mechanical retention by numerous methods. One method is to solder studs to the backplate.

\subsection{Shims}

Shims are metallic visco-elastic and laminates compounds. It is located (in the case of a floating caliper) between a caliper or piston housing and a backplate. They aim to damp disc-pad vibrations [29]. They are normally connected with an adhesive or manually assembled to the backplate. A shim can be seen in figure 4. Shims can be having viscoelastic material. 


\section{International Journal of Innovations in Engineering and Science, www.ijies.net}

\subsection{Brake caliper}

A brake caliper is an assemblage where brake pads are located. Furthermore, the brake caliper houses a pistons and supplies brake fluid channels that control pistons. Two types of calipers, floating and fixed, are available. Both pistons rotate and drive brake pads as friction is applied. When the disc surface is touched by the plate, the caliper travels in the opposite direction such that the disc surface is still touched by the outer plate. The inboard pad is often referred to as the piston-side pad in this style, and the outboard one is called the finger-side pad. Both pads typically display separate levels of touch pressure and wear behaviors[30] because of dissimilar reinforcement and actuating mechanisms and variations into thermal deformation of the disc's [31].

\section{III- FULL SOLID DISC BRAKES NUMERICAL ANALYSIS}

Kennedy and Ling[32] first reported thermal analysis coupled with mechanical variables such as thermo elasticity, wear, sliding contact, etc. They believed, whole friction force was transformed into kinetic energy and that there was macroscopic communication into the rotor of disc and pad. Rao et al.[33] have used this into slipping parts of disc brake assembly because of thermoelastic instability for their study of the difference in temperature in the disc brake because of repetitive braking (fade). Because of non-uniform heat flux generation at the disc surface, thermal stresses are generated. This may be minimized by changing a natural pressure (the disc and friction material are in contact) in reverse with the circular disc radius[34]. If this natural pressure does not differ evenly, it can lead to disc thermoelastic instability. Temperature gradients and thermal stresses are also greatly influenced by regular strain. This thermo-mechanical behavior is influenced by several influences, such as the dimension of the disc, the hydraulic piston, and the cross-section of the disc [35].

Distribution of pressure influences into a disc brake on temperature, heating growth, banding, wear were examined by Day et al.[36]. Developing a 2-D axissymmetric FE model with a disc brake diameter of 227 $\mathrm{mm}$ for the braking time of $4 \mathrm{~s}$, authors discovered that can be reduced by keeping a uniform pressure on the disc and pad contact surface[36]. Dufre'noy and Weichert[37] stated that non-uniform interaction into disc and pad depended on the braking method, in their research on interaction analysis conducted by ANSYS tools. Efficacy of the braking system and the important braking system configuration were obtained. This method of thermo-mechanical analysis involves the application of specific boundary conditions, such as the non-uniform distribution of pressure[37]. To measure the distribution of contact forces between the disc and the pad, Hohmann et al.[38] used the ADINA 7.1 spare solver. The findings revealed that to develop the friction brake system and to research the correct existence of pressure variation and deformation, a detailed examination of the interaction between the disc and pad was necessary[38]. Both heat transfer modes at the disc and wheel carrier interface were studied in another study conducted by Voller et al.[39] to find the difference in thermal resistance and its response to clamping strain. It was observed that the thermal energy dissipated during braking was influenced by all heat transfer modes due to interaction with the disc and the wheel carrier, as seen in Fig. 6 of [39]. The circumferential stress produced as a result of this action must be considered as a major component of stress, leading to stress failure [40].

Table 1 shows the comparative analysis of numerical analysis of simple solid disc.

Table 1 Comparative numerical analysis of simple solid disc

\begin{tabular}{|l|l|l|l|l|}
\hline References & Medium & $\begin{array}{l}\text { Material of Disc, } \\
\text { speed } \\
\text { and time }\end{array}$ & $\begin{array}{l}\text { Parameters considered } \\
\text { kmph, 2.36 s } \\
\text { observation }\end{array}$ \\
\hline$[34]$ & Train & $\begin{array}{l}\text { FC-250, } 100-50 \\
\text { kmpistribution of temperature, } \\
\text { distortion, } \\
\text { thermal fatigue, } \\
\text { and stresses }\end{array}$ & $\begin{array}{l}\text { Coning distortion, induced non- } \\
\text { uniform distribution of temperature }\end{array}$ \\
\hline$[35]$ & Mercedes & $100-0 \mathrm{rad} / \mathrm{s}$ & $\begin{array}{l}\text { Vibrations, Distribution of } \\
\text { pressure and temperature }\end{array}$ & $\begin{array}{l}\text { In actual contact, the distribution of } \\
\text { pressure is completely different } \\
\text { relative to flat surface contact. }\end{array}$ \\
\hline
\end{tabular}


International Journal of Innovations in Engineering and Science, www.ijies.net

\begin{tabular}{|c|c|c|c|c|}
\hline [38] & Train & $\begin{array}{l}\text { C.I., } 100-0 \mathrm{kmph}, \\
3.96 \mathrm{~s}\end{array}$ & Variations of temperature & $\begin{array}{l}\text { The friction coefficient must be } \\
\text { low to achieve low temperatures } \\
\text { during braking, which is difficult to } \\
\text { achieve. }\end{array}$ \\
\hline [41] & $\begin{array}{l}\text { Aircraft } \\
\text { Boeing }\end{array}$ & 747 brake material & Deformation of temperature & $\begin{array}{l}\text { Study based on contact area change } \\
\text { is extra effective compared to } \\
\text { continuous contact area change. }\end{array}$ \\
\hline [42] & $\begin{array}{l}\text { Travelers } \\
\text { vehicle }\end{array}$ & $65-0 \mathrm{kmph}, 45 \mathrm{~s}$ & Distribution of temperature & $\begin{array}{l}\text { In order to achieve improved } \\
\text { results, the disc and flange must be } \\
\text { treated as single. }\end{array}$ \\
\hline [43] & $\begin{array}{l}\text { Travelers } \\
\text { vehicle }\end{array}$ & Steel, $0.29 \mathrm{~s}$ & $\begin{array}{l}\text { Thermal stresses and } \\
\text { Distribution of temperature }\end{array}$ & $\begin{array}{l}\text { To escape thermal stress, heat flux } \\
\text { produced consistently. }\end{array}$ \\
\hline [44] & $\begin{array}{l}\text { Travelers } \\
\text { vehicle }\end{array}$ & Steel & Regular pressures & $\begin{array}{l}\text { Thermal deformation have a } \\
\text { significant influence upon the } \\
\text { natural distribution of pressure in } \\
\text { discs }\end{array}$ \\
\hline [45] & $\begin{array}{l}\text { Travelers } \\
\text { vehicle }\end{array}$ & $\begin{array}{l}\text { Grey C.I., } \\
100-0 \text { kmph, } 4 \mathrm{~s}\end{array}$ & $\begin{array}{l}\text { Wear, hot spots, and disc } \\
\text { coning }\end{array}$ & $\begin{array}{l}\text { To minimise thermal and } \\
\text { macroscopic effects, uniform } \\
\text { pressure is required. }\end{array}$ \\
\hline [46] & Train & $\begin{array}{l}\text { Steel, 155-0 kmph, } \\
62 \mathrm{~s}\end{array}$ & $\begin{array}{l}\text { Surfaces of the bearing, } \\
\text { thermal expansion, thermal } \\
\text { gradients and wear }\end{array}$ & $\begin{array}{l}\text { There's more to radial effects than } \\
\text { circumferential effects. The belief } \\
\text { that uniform pressure transfer is not } \\
\text { restrictive }\end{array}$ \\
\hline [47] & $\begin{array}{l}\text { Travelers } \\
\text { vehicle }\end{array}$ & & $\begin{array}{l}\text { Distribution of temperature, } \\
\text { contact } \\
\text { pressure }\end{array}$ & $\begin{array}{l}\text { Precise measurement of contact in } \\
\text { the pad and disc is necessary for } \\
\text { designing friction brakes. }\end{array}$ \\
\hline [48] & Train & $\begin{array}{l}\text { Grey C.I., } \\
90-8 \mathrm{kmph}, \\
720 \mathrm{~s} \\
\end{array}$ & $\begin{array}{l}\text { Heat transfer coefficient of } \\
\text { conduction/ convection / } \\
\text { radiation }\end{array}$ & $\begin{array}{l}\text { A major vary into thermal } \\
\text { emissivity on a disc surface }\end{array}$ \\
\hline$[49,50]$ & Train & $\begin{array}{l}\text { C.I., } \\
40 \mathrm{~s}\end{array}$ & $\begin{array}{l}\text { The temperature of the local } \\
\text { interface, coefficient of } \\
\text { friction, contact area }\end{array}$ & $\begin{array}{l}\text { Maximal temperature doesn't } \\
\text { linearly differ by dipping area of } \\
\text { contact. }\end{array}$ \\
\hline [51] & $\begin{array}{l}\text { Travelers } \\
\text { vehicle }\end{array}$ & $\begin{array}{l}100-0 \mathrm{rad} / \mathrm{s} 10,20 \\
\text { and } \\
80 \mathrm{~m}\end{array}$ & $\begin{array}{l}\text { Wear and } \\
\text { Distribution of temperature }\end{array}$ & $\begin{array}{l}\text { In relation to smooth surfaces, } \\
\text { higher temperature regions are } \\
\text { found on irregular surfaces. }\end{array}$ \\
\hline [52] & $\begin{array}{l}\text { Motor } \\
\text { cycle }\end{array}$ & $\begin{array}{l}\text { C.I., and Al alloy } \\
96.6-0 \mathrm{kmph}\end{array}$ & $\begin{array}{l}\text { Distribution of temperature, } \\
\text { Thermal expansion. }\end{array}$ & $\begin{array}{l}\text { High brake wear is due to the } \\
\text { thermal seizure between the drum } \\
\text { and the panel that has formed at } \\
\text { high temperatures. }\end{array}$ \\
\hline [53] & $\begin{array}{l}\text { Motor } \\
\text { cycle }\end{array}$ & $\begin{array}{l}\text { Al,S. steel and } \\
\text { C.I., } 31.2-0 \mathrm{~m} / \mathrm{s} \text {, } \\
4 \mathrm{~s}\end{array}$ & $\begin{array}{l}\text { Von mises stress, } \\
\text { Distribution of temperature }\end{array}$ & $\begin{array}{l}\text { Cast iron is better correlated with } \\
\text { structural and thermal efficiency } \\
\text { above all }\end{array}$ \\
\hline [54] & Car & $\begin{array}{l}\text { Grey C.I., BS } \\
50 \\
30-0 \mathrm{~m} / \mathrm{s}, 3 \mathrm{~s} \\
\end{array}$ & $\begin{array}{l}\text { Distribution of stress and } \\
\text { temperature }\end{array}$ & $\begin{array}{l}\text { Asbestos has caused environmental } \\
\text { and health harm to mats. Relatively } \\
\text { stronger are the aramid fibre pads }\end{array}$ \\
\hline
\end{tabular}




\section{International Journal of Innovations in Engineering and Science, www.ijies.net}

\section{IV-CONCLUSIONS}

A disc brake is a complex device and it needs knowledge across numerous fields such as tribology, metallurgy, fluid mechanics, vibrations, etc. to consider various problems related to its nature and function. Because of the comprehensive study, disc brakes have grown immensely over the decades. Many phenomena remain that are not completely established.

It is important to further build non-linear finite element models for accurate numerical research of disc brake systems, which could simulate actual touch interface evolution. These models should, at least, be capable of incorporating a practical model of friction and wear and temperature-dependent material properties.

A systematic study of the computational and theoretical work on solid disc brake research and construction has been carried out. While utmost precaution has been taken to review all the records available, due to lack of usability, omissions will occur. The authors reviewed the literature, categorized it as numerical and experimental research, and gave recommendations for future study. The study into the area dates back to the early nineteenth century, and with the introduction of computational methods and modern research instruments, it made remarkable success after the 1970s. Researchers have commonly used numerical approaches for evaluating disc brake and pad thermal, mechanical, and structural ehaviors. Various research on material alteration, braking conditions, braking length, assumptions, application field, etc. have been published.

\section{REFERENCES}

[1] P. Lingman. Integrated brake control downhill driving strategies. PhD thesis, Chalmers Tekniska Hogskola, 2006.

[2] Apte AA, Ravi H (2006) FE prediction of thermal performance and stresses in a disc brake system. In: Commercial vehicle engineering congress and exhibition. SAE Technical Paper Series 2006-01-3558

[3] Cho C, Ahn S (2002) Transient thermoelastic analysis of disk brake using the fast fourier transform and finite element method. J Therm Stress 25(February):215-243

[4] McPhee AD, Johnson DA (2008) Experimental heat transfer and flow analysis of a vented brake rotor. Int J Therm Sci 47(4):458-467

[5] Kao T, Richmond JW, Moore MW (1994) The application of predictive techniques to study thermoelastic instability of brakes. In: 12th annual brake colloquium and engineering display. SAE Technical Papers 942087

[6] Hartsock DL, Fash JW (2000) Effect of pad/caliper stiffness, pad thickness, and pad length on thermoelastic instability in disk brakes. J Tribol 122(3):511
[7] Panier S, Dufrénoy P, Weichert D (2004) An experimental investigation of hot spots in railway disc brakes. Wear 256(7-8):764-773

[8] Shelare S.D., Kumar R., Khope P.B. (2021) Formulation of a Mathematical Model for Quantity of Deshelled Nut in Charoli Nut Deshelling Machine. In: Prakash C., Krolczyk G., Singh S., Pramanik A. (eds) Advances in Metrology and Measurement of Engineering Surfaces. Lecture Notes in Mechanical Engineering. Springer, Singapore

[9] Jung SP, Park TW, Chai JB, Chung WS (2011) Thermo-mechanical finite element analysis of hot judder phenomenon of a ventilated disc brake system. Int J Precis Eng Manuf 12(5):821-828

[10] C. Owen. Automotive Brake Systems, Classroom Manual. Today's Technician. Delmar Cengage Learning, 2010.

[11] Kinkaid NM, O'Reilly OM, Papadopoulos P (2003) Automotive disc brake squeal. J Sound Vib 267(1):105-166

[12] Jawalekar, S. B., and S. D. Shelare. 2020. Development and performance analysis of low cost combined harvester for rabicrops. Agricultural Engineering International:CIGR Journal, 22 (1):197-201.

[13] Berger E (2002) Friction modeling for dynamic system simulation. Appl Mech Rev 55(6):535-577

[14] Wu Y, Wei Y, Liu Y, Duan Z, Wang L (2017) 3-D analysis of thermal-mechanical behavior of wheel/rail sliding contact considering temperature characteristics of materials. Appl Therm Eng 115:455-462

[15] Belhocine A, Omar WZW (2017) Predictive modeling and simulation of the structural contact problems between the brake pads and rotor in frictional sliding contact. Int J Interact Des Manuf 12(1):63-80

[16] Mathew J.J., Sakhale C.N., Shelare S.D. (2020) Latest Trends in Sheet Metal Components and Its ProcessesA Literature Review. In: Sharma H., Govindan K., Poonia R., Kumar S., El-Medany W. (eds) Advances in Computing and Intelligent Systems. Algorithms for Intelligent Systems. Springer, Singapore

[17] Dufre'noy P, Basket SS, Weichert D (1998) Study on hot spots in the brakes to railway disc. Eur Brake Days 245-257

[18] Evtushenko OO, Ivanyk EH, Horbachova NV (2000) Analytic methods for thermal calculation of brakes (review). Mater Sci 36(6):857-862

[19] Ghadimi B, Kowsary F, Khorami M (2013) Thermal analysis of locomotive wheel-mounted brake disc. Appl Therm Eng 51(1-2):948-952

[20] Waghmare S., Mungle N., Tembhurkar C., Shelare S., Sirsat P., Pathare N. (2019) Design and Analysis of Power Screw for Manhole Cover Lifter. International Journal of Recent Technology and Engineering, Volume 8, Issue 2, July 2019. Pp. 2782-2786, DOI: 10.35940/ijrte.B2628.078219 


\section{International Journal of Innovations in Engineering and Science, www.ijies.net}

[21] Yenerer H, Bakır M, O” zmen B (2016) Detailed strength analyses of drum brakes used in light and heavy duty trucks. In: 8. Otomotiv Teknolojileri Kongresi. pp 1120-1125

[22] Waghmare S.N., Shelare S.D., Tembhurkar C.K., Jawalekar S.B. (2021) Development of a Model for the Number of Bends During Stirrup Making Process. In: Prakash C., Krolczyk G., Singh S., Pramanik A. (eds) Advances in Metrology and Measurement of Engineering Surfaces. Lecture Notes in Mechanical Engineering. Springer, Singapore

[23] So"derberg A, Andersson S (2009) Simulation of wear and contact pressure distribution at the pad-to-rotor interface in a disc brake using general purpose finite element analysis software. Wear 267(12):2243-2251

[24] S.C. Lin, C.C. Guan, A.R.A. Bakar, M.R. Jamaluddin, M.M.W. Wan Harujan, and B.A. Ghani. Disc brake squeal suppression through chamfered and slotted pad. International Journal of Vehicle Structures and Systems, 3(1):28-35, 2011.

[25] Waghmare S., Shelare S., Sirsat P., Pathare N, Awatade S. (2020) Development Of An Innovative MultiOperational Furnace. International Journal of Scientific \& Technology Research Volume 9, Issue 04, April 2020. Pp 885-889.

[26] M. Eriksson, F. Bergman, and S. Jacobson. On the nature of tribological contact in automotive brakes. Wear, 252(1-2):26-36, 2002.

[27] K. Lee and J.R. Barber. An experimental investigation of frictionally-excited thermoelastic instability in automotive disk brakes under a drag brake application. Journal of Tribology, 116(3):409-414, 1994

[28] L. Matozo, A. Menetrier, and A. Tamagna. Analysis of high damping underlayer materials for brake pads and its effects on NVH performance. SAE Technical Paper, pages 01-3223, 2006.

[29] A.M. Balvedi and S.N.Y. Gerges. Squeal noise in disc brakes and the influence of damping on the system dynamic stability. Acta Acustica united with Acustica, 94(2):254-264, 2008.

[30] A.R. AbuBakar and H. Ouyang. Wear prediction of friction material and brake squeal using the finite element method. Wear, 264(11-12):1069-1076, 2008.

[31] S. Koetniyom. Thermal Stress Analysis of Automotive Disc Brakes. PhD thesis, University of Leeds, 2000.

[32] Kennedy FE, Ling FF (1974) A thermal, thermoelastic, and wear simulation of a high-energy sliding contact problem. J Lubr Technol 96(3):497-505

[33] Rao VTVSR, Ramasubramanian H, Seetharamu KN (1989) Analysis of temperature field in brake disc for fade assessment. Warme- und Stoffiibertragung 24(1):9-17

[34] Zagrodzki P (1985) Numerical analysis of temperature fields and thermal stresses in the friction discs of a multidisc wet clutch. Wear 101(3):255-271
[35] Zagrodzki P (1990) Analysis of thermomechanical phenomena in multidisc clutches and brakes. Wear 140(2):291-308 9. S. Koetniyom, P.C. Brooks, and D.C. Barton.

[36] Day AJ, Tirovic M, Newcomb TP (1991) Thermal effects and pressure distributions in brakes. Proc Inst Mech Eng Part D J Automob Eng 205:199-205

[37] Dufre'noy P, Weichert D (1995) Prediction of railway disc brake temperatures taking the bearing surface variations into account. Arch Proc Inst Mech Eng Part F J Rail Rapid Transit 1989-1996 (vols 203-210) 209(26):67-76

[38] Hohmann C, Schiffner K, Oerter K, Reese H (1999) Contact analysis for drum brakes and disk brakes using ADINA. Comput Struct 72(1):185-198

[39] Voller GP, Tirovic M, Morris R, Gibbens P (2005) Analysis of automotive disc brake cooling characteristics. Proc Inst Mech Eng Part D J Automob Eng 217(8):657-666

[40] Choi J-H, Lee I (2003) Transient thermoelastic analysis of disk brakes in frictional contact. J Therm Stress 26(3):223-244

[41] Nathi GM, Charyulu TN, Gowtham K, Reddy PS (2012) Coupled structural/thermal analysis of disc brake. Int J Res Eng Technol 1(4):539-553

[42] Belhocine A (2017) FE prediction of thermal performance and stresses in an automotive disc brake system. Int J Adv Manuf Technol 89(9-12):3563-3578

[43] Xusheng HJGCTX, Xiezhao LIN (2008) Numerical modeling and analysis of the thermal-structure coupling of the disc brake. Chin J Mech Eng 2:26

[44] Belhocine A, Bouchetara M (2013) Thermomechanical stress analysis of vehicles gray cast brake. J Serb Soc Comput Mech 7(1):17-27

[45] Belhocine A, Bouchetara M (2012) Thermomechanical modelling of dry contacts in automotive disc brake. Int J Therm Sci 60:161-170

[46] Belhocine A, Bouchetara M (2012) Simulation of fully coupled thermomechanical analysis of disc brake rotor. WSEAS Trans Appl Theor Mech 7(3):169-181

[47] Yevtushenko AA, Kuciej M, Yevtushenko O (2011) Threeelement model of frictional heating during braking with contact thermal resistance and timedependent pressure. Int J Therm Sci 50(6):1116-1124

[48] Choi JH, Lee I (2004) Finite element analysis of transient thermoelastic behaviors in disk brakes. Wear 257(1-2):47-58

[49] Ali B, Ghazaly NM (2013) Thermal modeling of disc brake rotor in frictional contact. J Multiscale Model 5(3):1350013

[50] Belhocine A, Bouchetara M (2013) Temperature and thermal stresses of vehicles gray cast brake. J Appl Res Technol 11(5):674-682

[51] Yevtushenko AA, Adamowicz A, Grzes P (2013) Three-dimensional FE model for the calculation of temperature of a disc brake at temperature-dependent 
Vol. 5 , No. 12, 2020, PP. 1-8

International Journal of Innovations in Engineering and Science, www.ijies.net

coefficients of friction. Int Commun Heat Mass Transf 42:18-24

[52] Yevtushenko AA, Kuciej M (2010) Influence of the convective cooling and the thermal resistance on the temperature of the pad/ disc tribosystem. Int Commun Heat Mass Transf 37(4):337-342

[53] Babukanth G, Teja MV (2012) Transient analysis of disk brake by using ansys software. Int J Mech Ind Eng 2(1):21-25

[54] Chang L (2003) Finite element simulation of thermoelastic coupling characteristics of automotive drum brake. J Mech Strength 4:11 